\title{
EchoGéo
}

$57 \mid 2021$

Les enjeux de l'alimentation en eau potable des villes

\section{Hydraulic bricolages: coexisting water supply and access regimes in N'Djamena, Chad}

Ismaël Maazaz

\section{OpenEdition}

1 Journals

\section{Electronic version}

URL: https://journals.openedition.org/echogeo/22514

DOI: $10.4000 /$ echogeo.22514

ISSN: 1963-1197

\section{Publisher}

Pôle de recherche pour l'organisation et la diffusion de l'information géographique (CNRS UMR 8586)

\section{Electronic reference}

Ismaël Maazaz, "Hydraulic bricolages: coexisting water supply and access regimes in N'Djamena, Chad", EchoGéo [Online], 57 | 2021, Online since 01 December 2021, connection on 01 December 2021. URL: http://journals.openedition.org/echogeo/22514 ; DOI: https://doi.org/10.4000/echogeo.22514

This text was automatically generated on 1 December 2021

EchoGéo est mis à disposition selon les termes de la licence Creative Commons Attribution - Pas d'Utilisation Commerciale - Pas de Modification 4.0 International (CC BY-NC-ND) 


\title{
Hydraulic bricolages: coexisting water supply and access regimes in N’Djamena, Chad
}

\author{
Ismaël Maazaz
}

\section{Introduction}

Chad is a 16 million inhabitants, 1.3 million square kilometres landlocked state in Central Africa which usually ranks among the lowest developed countries in the world with more than $50 \%$ of the population living below the poverty line (World Bank, 2019). Chadian history has been marred with conflicts, influencing state formation and lifestyles in periods of "interwar" (Debos, 2016). Industrial oil extraction picked up steam in the early 2000s and associated revenues quickly rose to dominate the state budget (Magrin, 2001; Magrin and Van Vliet, 2012; Magrin and Perrier-Bruslé, 2011). The backlash induced by oil prices slump in the mid-2010s plunged the country into its worst economic crisis in decades.

Much of the available quantitative data on water access and availability in Chad are poor and unreliable. For example, a report commissioned by the United Nation's Children Fund (UNICEF) and the Chadian Ministry of Water, Environment and Fishery (2017) mentions an access rate to drinking water in the Lake province of $101.21 \%$ (!). Likewise, the Joint Monitoring Programme (JMP) created by the World Health Organisation and UNICEF reports access to drinking water of around $96 \%$ in N'Djamena but these figures are questionable as they conflate disparate water sources and qualities (fountains, hand pumps, private water connections). In particular, N'Djamena's waterscape remains highly uncertain. Uncertainties partly result from the multiplicity of water sources in the Chadian capital. 
Illustration 1 - Improved water access per region in Chad

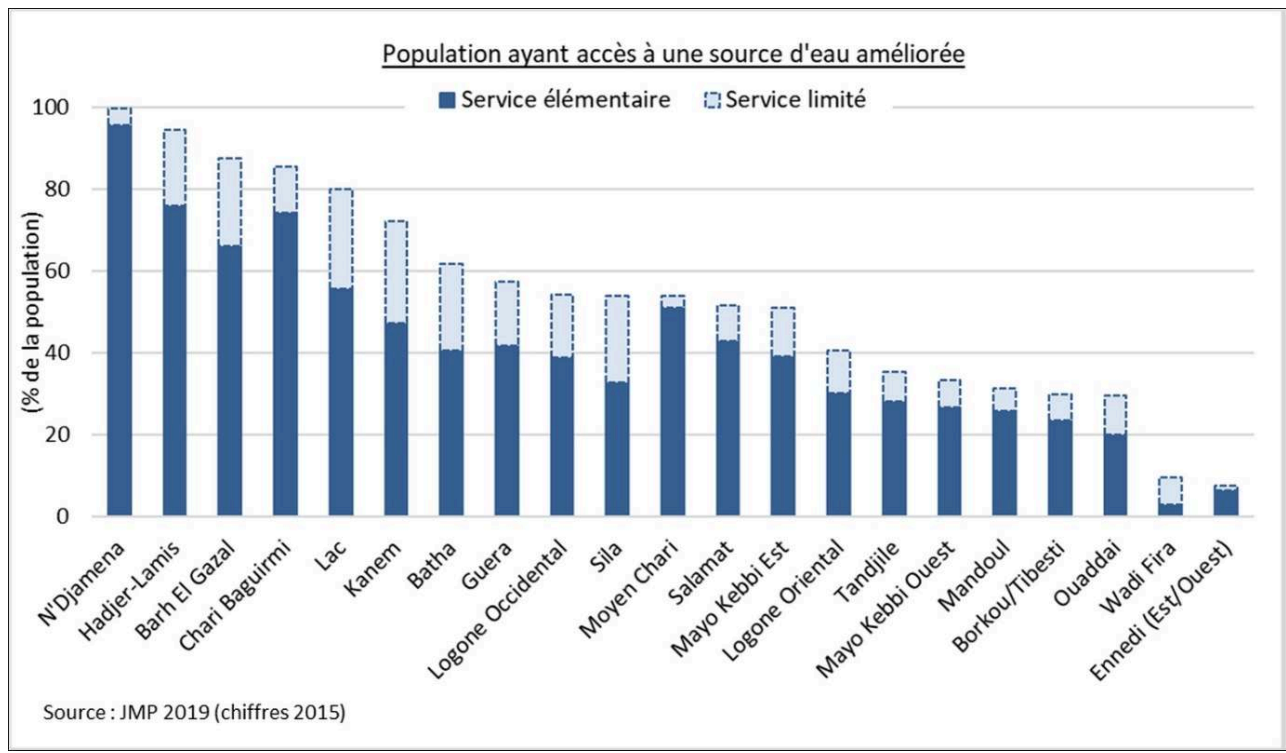

Source: JMP, 2019

This article ${ }^{1}$ explores the multifarious facets of water supply in N'Djamena as a city deprived from a universal water supply scheme through an original lens. It documents the Société Tchadienne des Eaux (Chad's national water company, STE) operations and argues that series of locally managed, multi-layered water supply regimes coexist in N'Djamena. Sociotechnical regimes are defined as "relatively stable configurations of institutions, techniques and artefacts, as well as rules, practices and networks that determine the 'normal' development and use of technologies" (Rip and Kemp, 2004; Smith et al., 2005, p. 1493). As such, "hydraulic regimes" are sets of technical, political, legal and social norms regulating supply and access to water. In N'Djamena, these regimes, or this multi-layered regime, widely escape the infrastructural network of Chad's national water company. This leads end-users and water workers to devise their own multisource water access or distribution solutions, producing what I term "hydraulic bricolages". Bricolages combine production (industrial catchment, hand pumping, boreholes...) and distribution services (water porting, shared-supply and counting $)^{2}$. While development projects funded by donors like the French Development Agency (AFD) and the European Union (EU) aim at expanding networks and enhancing integration of water infrastructural networks, contrived working environments on the ground contribute to sustain the hydraulic bricolages and the associated multi-layered regimes in N'Djamena. Among these are associated connection costs and widespread reliance over private boreholes across many neighbourhoods.

This paper draws on materials I collected throughout 12 months of doctoral field research in N'Djamena in 2019. I led around 10 semi-structured interviews with mid-tohigh level managers of the Direction technique (Technical Directorate, DT) of the STE. Later, I formally applied for a stage d'observation (observatory internship) at the DT. My application was accepted and I was assigned to the maintenance and Travaux neufs ${ }^{3}$ (New Works) teams of the DT for 7 days. This internship consisted in following the STE agents in their daily job, helping out on carrying tools or other materials, taking notes and numerous photographs as well as having multiple informal conversations with the agents while they were working or during their breaks. After the week of internship, I 
followed up with additional exchanges with the agents and managers I had previously interviewed. I also use materials collected during interviews with a dozen of neighbourhood association members, municipal officers and water end-users. Although I was unable to travel back to N'Djamena in 2020 and 2021 because of the COVID-19 pandemic, my research collaborator sent me updated information about field sites we visited in 2019.

\section{Analysing water supply and access in N'Djamena}

\section{Prevailing and evolving paradigms}

Water supply schemes have attracted a wide scholarly attention in urban studies as part of a broader interest for infrastructural networks in Western cities. Earlier writings have explored the rise of the "networked city" against the backdrops of the implementation of infrastructural networks from the XIX ${ }^{\text {th }}$ century onwards, in Europe and North America (e.g: Hughes, 1987; Tarr, 1979). The "splintering urbanism" thesis entered the scene in the early 2000s (Graham and Marvin, 2001). This influential lens posited a declining "modern infrastructural ideal" sapped by the triumphant neoliberal ideology. It stressed the ongoing "unbundlings" of infrastructural networks in cities that used to comprise integrated, publicly managed systems. More broadly, Graham and Marvin paint infrastructures as the critical aspect of modern cities. Infrastructures sustain "sociotechnical geometries of power" (2001, p. 11) and spread unevenly across urban spaces, generating internal barriers and fuelling struggles.

6 The literature later analysed, nuanced, updated and revised the path-breaking contributions of the splintering urbanism thesis. The absence of integrated networks in numerous urban contexts has undermined the replicability of the paradigm (Coutard, 2008). Rather than networks, water supply schemes in developing countries have been portrayed as "archipelagos", or "spatially separated but linked 'islands' of networked supply in the urban fabric" (Bakker, 2003, p. 337). For similar reasons, empirical evidence underscored that water supply schemes of cities like Jakarta (Kooy and Bakker, 2008), Mumbai (Zérah, 2008), Khartoum (Crombé, 2017) as well as a range of Sub-Saharan African cities (Jaglin, 2005) would not fit into the splintering urbanism paradigm. Likewise, such paradigm hardly captures the multiplicity of water supply schemes in N'Djamena, which complex infrastructural landscape is reminiscent of other developing countries.

Beyond network analysis, literature reviews have insisted on cultural habits and localscale analysis as critical to rethink urban waterscapes (Lavie et al., 2020). Similarly, scholarly calls to explore "beyond the networked city" (Coutard and Rutherford, 2016) resonate with studies pointing at a "pragmatic turn" (Jaglin, 2016) of policy-makers who now recognise so-called "informal" (Ahlers et al., 2014) or "alternative" (Furlong, 2016) service delivery solutions. In the peripheries of Khartoum for instance, "micronetworks" built around boreholes at the neighbourhood scale have been gradually replacing water porting and similar water delivery solutions (Crombé and Blanchon, 2010). Such micro-networks mimic standard, universal water provision schemes but without central system coupling. In Khartoum, they participate in urban waterscape fragmentation (Crombé and Blanchon, 2010, p. 524). Conversely, micro-networks of Mendoza (Argentina) have spread around archipelagos in newly urbanised areas 
without fully countering endeavours towards network universalisation (Lavie and Marshall, 2019). In Douala (Cameroon), the fragmentation of public water services has opened multiple opportunities for informal practices and politicians-entrepreneurs (Big men) to organise the water supply market (Nantchop Tenkap, 2017).

8 Policy circles have gradually acknowledged these unorthodox schemes as enduring "hybrid delivery" (Jaglin, 2016, p. 188) or "heterogeneous infrastructure" (Lawhon et al., 2018) configurations. Authors have thought beyond infrastructural uniformity and universality to emphasise sociotechnical coexistence in the Global South (Furlong, 2014, p. 140). In Chad though, policy narratives regularly emphasise central network expansion as a standard solution to water problems: for instance, several institutional documents equate "water access" with increased connection to the piped network resulting from network expansion and subsequent subscriptions to the STE. On the one hand, this is consistent with historically dominant paradigms on large technical systems in Western contexts, which often insist on infrastructural "transitions" (Furlong, 2014). On the other hand, such narratives are often at odds with workers and end-users' daily experiences of constantly juggling with multifarious resources and "tactics" (Certeau, 1984) to provide and access water ${ }^{4}$. Therefore, the notion of hydraulic bricolages I mobilise in this article is useful to grasp with the "makeshift" processes devised by both end-users and water professionals like STE workers. Following the work of AbdouMaliq Simone (2018, p. 18), makeshift refers not to reckless spontaneity but to "calibrations and measures" in contexts of heavy constraints, offering supposedly temporary solutions that end up permanent. Hydraulic bricolages also echo what Jonathan Silver (2014) terms "incremental infrastructures" to examine electricity networks in Accra, Ghana. Bricolage of water provision schemes does not equate improvisation, although both ideas are closely associated on the ground, as I discuss below in a section on N'Djamena's waterscape.

\section{N'Djamena's waterscape}

Illustration 2 - Physical map of N'Djamena and its arrondissements (districts) along the Chari river

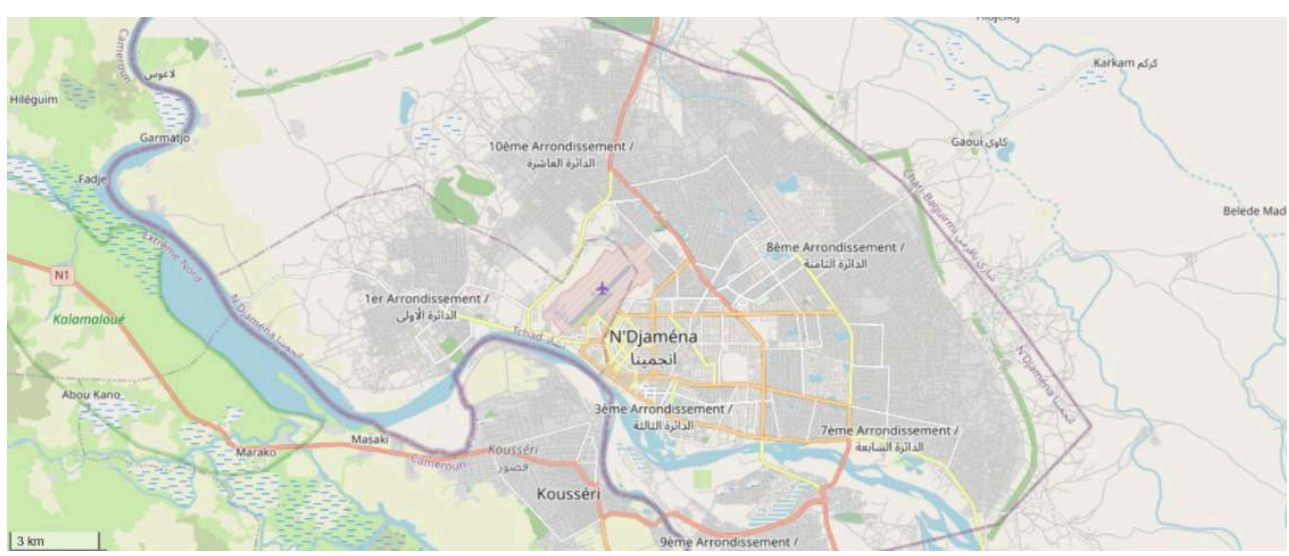

The Cameroonian border and the twin town of Kousséri lie in the Southern bank of the Chari.

Source: Open Street Map.

9 N'Djamena, the Chadian political capital, is located in a flat alluvial plain in the Sahelian zone at the West-Centre of Chad. It lies on the shores of the Chari river, around 100 kilometres South of Lake Chad. Its climate is semi-arid with a long dry 
season and briefer wet one. On average, N'Djamena rises at 293-298 metres above the mean sea level, lower than the Chari waters (297 metres) that gently slop northwards to the city. This particular topography causes massive flooding during rainfalls, which normally occur between May-June and September-October.

N'Djamena was founded as Fort-Lamy in 1900. It initially formed a small military outpost set up by French colonial officers in the aftermaths of the battle of Kousséri (now in Cameroon), its twin town on the other bank of the Chari. From its foundation onwards, the city has been roughly divided into three main components, organised in concentric circles (Ngaressem, 1998, p. 66). First, the "old colonial core" (mostly districts 1 and 2) or European city. Sometimes called Quartier résidentiel, administratif et financier (Residential, administrative and financial neighbourhood, QRAF), it is located on the bank of the Chari river nearby the airport in the centre to the NorthWest. It contains most administrative and financial institutions along with affluent houses. Second, the so-called "African city" (districts 3, 4, 5), Eastwards and Northwards, which hosts both working-class populations and historic notabilities or elites. It is the site of bustling trade but counts fewer socioeconomic equipment than the core. Finally, the peripheral neighbourhoods further East and North East (districts 7, 8 and $10^{5}$ ), concentrate most of the contemporary urban growth, with very limited equipment and infrastructures. Akin to other postcolonial African cities, some colonial divisions have partly persisted and framed contemporary urban class fault lines and territories: while so-called "traditional houses" are located in the former African city, the former QRAF still hosts many members of the elite and expatriate communities.

11 The city has been fast-growing over the past decades. It is said to host between 1 and 1.5 million inhabitants (Madjigoto 2019), against roughly 500,000 in 1993 and 10,000 in 1937 (Vivien, 2006). Urban organisation and land conversion remain globally unchecked insofar as policy-makers have issued few planning documents since the 1990s. Preliminary studies towards a master plan advised to expand the city westwards and controlling spatial arrangements on the shores of the Chari (MATUH and Mairie de N'Djamena, 2008). More than 10 years later, public officials have ignored the guidelines and let expansion occur informally in the $7^{\text {th }}$ and $8^{\text {th }}$ districts. These vast, newer districts are ill-equipped with basic infrastructures and inhabitants mostly rely on selforganisation to access basic services, foremost among them drinkable water.

In recent years, the scholarship has discussed bodies of water in Chad and associated socio-political dynamics: for instance Lake Chad has captured substantial attention (Chauvin et al., 2020; Raimond et al., 2019; Magrin, 2016). Yet, the literature has been more scant on water politics in N'Djamena. Unlike many Chadian regions, N'Djamena and its surroundings hold extensive groundwater reserves. It also remains the only Chadian city with an extended supply network as it concentrates $51 \%$ of STE subscribers and $80 \%$ of STE water deals (World Bank, 2019). Available data show evolutions since the 1990s, when the Chadian capital's population was less than half as it is now. The then-Société Tchadienne d'eau et d'électricité (Chadian water and electricity company, STEE) operated 11 deep boreholes (25-70 metres deep) mostly located in the city centre, including 6 set up in the 1970s through contributions of the European Development Fund (N'Diekhor 1996). In the 1990s, 38 \% of users relied on artisanal wells and only $1 \%$ of the households declared collecting surface water for domestic consumption, mostly from the Chari river (Ngaressem 1998). By contrast in 2019, 
19 boreholes connected to the STE network produced 12 million $\mathrm{m}^{3}$ yearly, around $40,000-45,000 \mathrm{~m}^{3}$ daily, but a city that size needs more than $100,000 \mathrm{~m}^{3}$ per day. This implies that barely one third of N'Djamenois can rely on this network (Madjigoto, 2019, p. 46).

Illustration 3 - STE's water pipe network map in N'Djamena in 2019

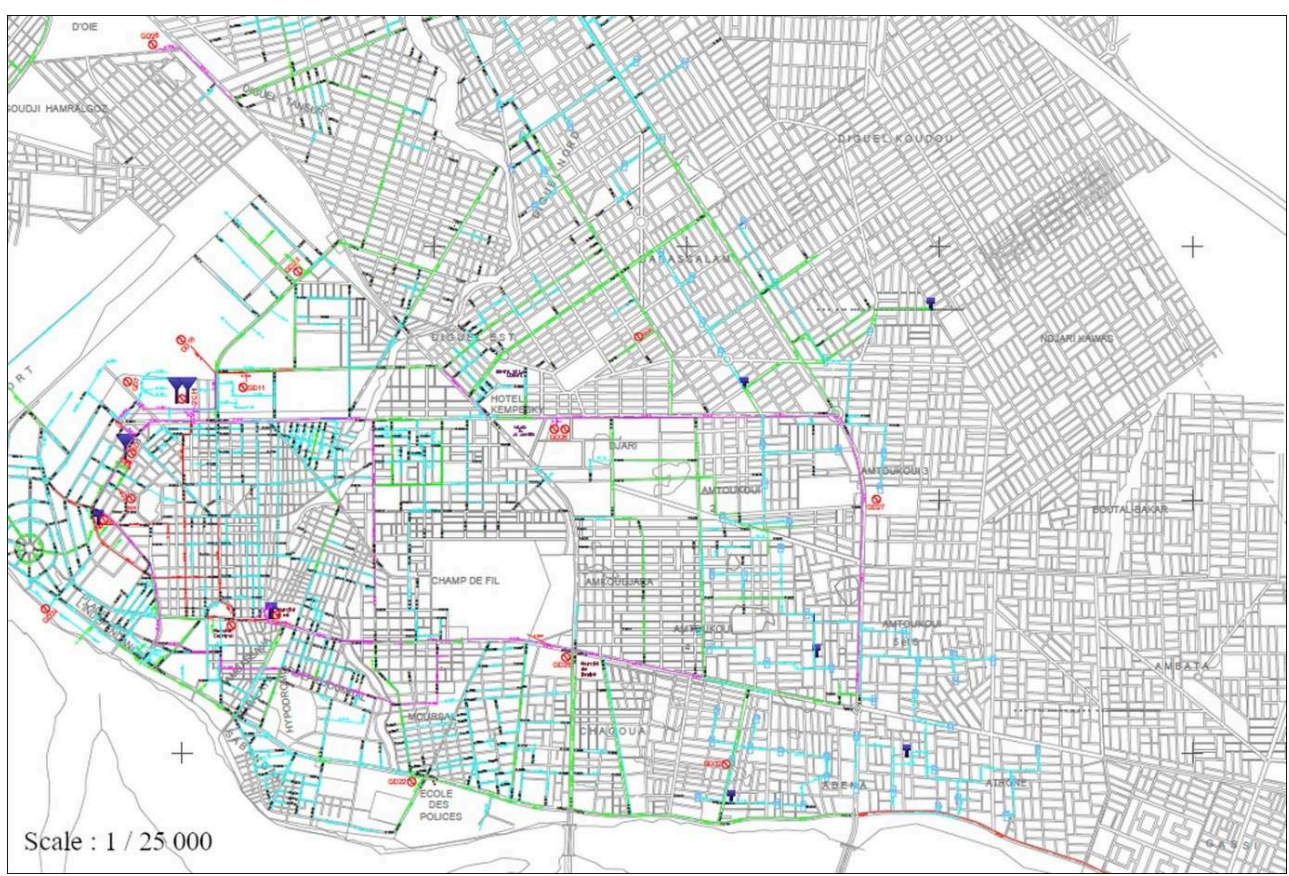

Courtesy of the STE.

STE water tariffs are heavily subsidised and remain comparatively low. Water pricing follows increasing-block tariffs (IBT) designed to protect smaller water consumers: rates increase with consumption.

Tableau 1 - Water tariffs in N'Djamena in 2018

\begin{tabular}{|l|l|l|}
\hline & Volumes (m3) & Prices (FCFA/m3) \\
\hline Threshold 1 & 0 to 6 & 200 \\
\hline Threshold 2 & 6,1 to 15 & 320 \\
\hline Threshold 3 & 15,1 to 50 & 405 \\
\hline Threshold 4 & More than 50 & 620 \\
\hline Fountains & N/A & 320 \\
\hline
\end{tabular}

Source: STE, Technical Directorate.

Private STE connections provide more affordable water than fountains or ported water. Porters usually sell 240 litters ( 12 jerry cans of 20 litters) for 500 francs ( 0.77 euros). Fountain managers sell water to porters or directly to customers at fixed rates ${ }^{6}$. 
However, entry costs and technical limitations prevent many households to subscribe to the STE for home tap water. Would-be subscribers need to set up a water counter (or meter), an investment which often costs more than 100000 FCFA, 146 euros (World Bank, 2019). Added to fees piling up, new customers reportedly pay up to 300,000 FCFA (438 euros), a considerable amount when compared with the chadian monthly minimum wage (60,000 FCFA, 92 euros). Therefore, the IBT strategy seems to be partly inefficient as some wealthy STE subscribers can enjoy lower tariffs while many poorer end-users remain out of the system and need to pay for expensive water.

As such, most water end-users rely on series of private systems, like boreholes, water pumps, wells, water porting and vending. Not all disconnected users are poor: various luxury hotels or villa owners prefer to use private boreholes ${ }^{7}$ (World Bank, 2019). Hand pump users are mostly located in working-class and peripheral neighbourhoods though. A 2017 study undertaken in the $7^{\text {th }}$ and $8^{\text {th }}$ district of the city reports that $44 \%$ of the respondents used private hand pumps and another $35 \%$ used shared hand pumps (Université Populaire, 2017, p. 13-14). Water quality remains concerning: a 2018 sampling of 50 water boreholes across the city reveals that $58 \%$ of them offer water which is unsuitable for consumption under World Health Organisation norms, mainly due to contaminations by germs (Laboratoire National des Eaux, 2018). Contaminations allegedly result from insufficient borehole depth leading to contacts with sewage systems, weak superstructures protecting water works like hand pumps and accelerating oxidation as well as poor sanitation practices around collective sources.

\section{Daily routines and network transformations: activities of the STE teams}

\section{Everyday maintenance and new works}

N'Djamena's complex waterscape fosters hydraulic bricolages. Even though they are not always visible, the multifarious endeavours of STE agents to set water into motion, connect new subscribers, maintain and extend the piped network are illustrative of these bricolages. The STE fully oversees the industrial cycles of water provision and operates catchment and distribution of water across urban areas of Chad (GWOPA/UN Habitat and DFID, 2015). The everyday operations and working conditions of field teams of the Technical Directorate of the STE are worth analysing as they inform about these hydraulic bricolages on the distribution side.

Breakdowns and failures are meaningful events that render infrastructures visible, indirectly excavating processes through which technical objects "define their world" (Akrich, 1989, p. 37) Repair is a "subtle act of care" (Jackson, 2014, p. 222) which pinpoints the inherent fragility of sociotechnical systems. In developing countries, constraints make repair a "vital source of variation, improvisation and innovation" (Graham and Thrift, 2007, p. 6). Stephen Graham and Nigel Thrift (2007, p. 6) refer to the "bodged job, which still allows something to continue functioning but probably at a lower level". Botched jobs are routine around N'Djamena's water schemes where networks and machines often under-function, requiring constant attention or risking abandonment. Parts of the core distribution network rests on loops and branches established in the 1960s and 1970s, based on concrete pipes (N'Diekhor, 1996). Such pipes are fragile and often unreliable, leading to breakages. Complex systems like 
infrastructural networks often hang by a thread in N'Djamena; professionals of maintenance and repair need to push materials to their limit or use tools in contradiction with their defined purposes. STE activities often appear as a "giant system of repair and improvisation" (Graham and Thrift, 2007, p. 11). Improvisation holds together things which split otherwise through "strange alliances" (Simone, 2018, p. 28). The reign of improvisation does not preclude regulations though, with which constantly interacts to design infrastructures and frames future relations of power and inequality (Mains, 2019).

Maintenance teams often deal with broken pipes entailing subsequent water leakage and flood, but pressure problems are also common. One of the DT maintenance teams I followed once visited the house of a STE customer whose operational voucher literally read "lack of water" (manque d'eau). Social and material relations mediate water pressure thereby operationalising differentiated accesses to water in various cities in developing countries (Anand, 2011). In the case I witnessed, extending pipes up to the "node" or pipe junction helped resolve the issue. During this operation, STE agents dug pipes and connected them to the junction. I watched them prepare the shaft collar through making it incandescent to soften it. They gathered pieces of wood and set them on fire. The also softened the PVC pipes with fire. It was routine, as they explained. STE workers worked by a shining sun. The physical intensity of the work made rotations every 20-30 minutes inevitable and increased drastically its duration. Beginning early in the morning, the operation extended until the nightfall. STE agents voiced constant frustrations arising from the fact that adequate materials would considerably facilitate maintenance and connection operations. It became obvious they could have done this job in a handful of hours with suitable tools. Makeshifts and improvisation also appear in the active role played by STE customers in the manipulations of pressure. STE customers improvise alongside the agents to adapt to challenging field conditions. During the above-mentioned pressure manipulation operation, the customer guided the agents in their work. He mused on inserting the pipe through the external walls of his house to reach the courtyard. After trials and pondering, he finally suggested breaking portions of the access ramp of his main house gate to let the pipe run through the entrance and connect it. The agents followed his suggestions. 
Illustration 4 - STE agent digging a hole nearby a valve to regulate water pressure

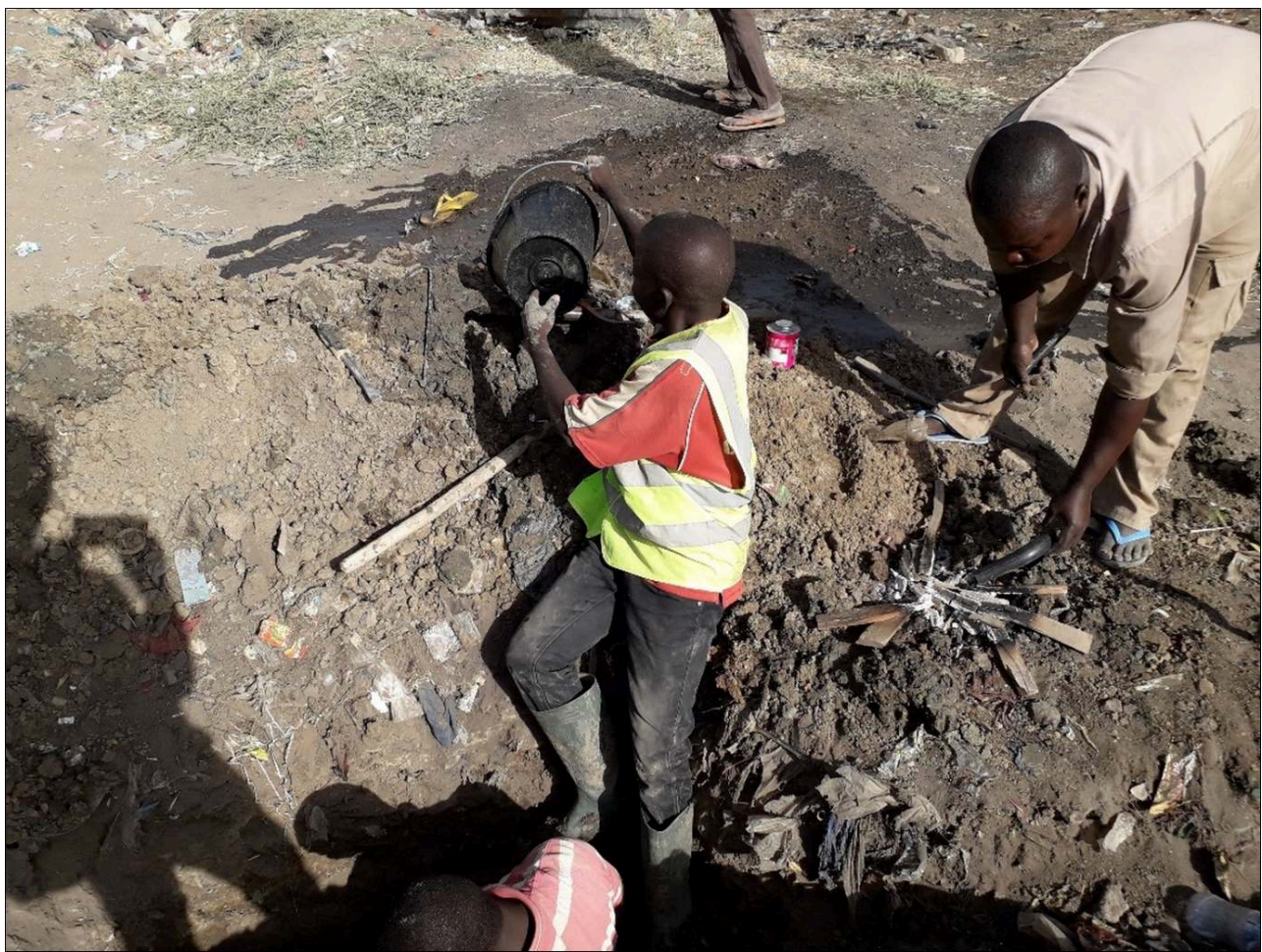

Author: I. Maazaz, 2019 work began. They carried out most activities manually, making the work hazardous, tedious and long. Pumps and generators were often expected to be used before agents realise they are faulty or missing. One morning, STE agents and I left the DT to join a team already onsite fixing a serious pipe leakage nearby a road of Farcha, $1^{\text {st }}$ district. The land and part of the road were entirely flooded. The broken pipe was one of the old concrete ones set up in the 1960s. As such, it was impossible to replace the pipe segment and workers needed to seal the leakage manually. When we arrived, we carried a power generator, useful to help pump water out of the holes... but no fuel was available to operate it. Whether fuel would be supplied soon or not was unclear to everyone, as hearsays and contradictory statements spread around. Following initial confusion and in lack of other options, workers began to dig with shovels, building a trench across the hole to evacuate buckets of water. The sun was relentlessly skimming the worker digging down the hole while temperatures neared 45 degrees Celsius. In the hole, only one agent could work while the others rested by the shade, rotating every 20 or 30 minutes. One of the younger workers finally acknowledged that fuel for the generator would probably never be available... although nobody could confirm it and uncertainties prevailed until the job ended, also at the end of the day.

In addition to the material glitches and hardships, the administrative cut between water and electricity services punctually entails confusions. In 2010, the STEE was broken down into two separate entities to set apart electricity and water public services, giving birth to the Société Nationale d'Electricity (National Electricity company, SNE) and the STE. However, this split has had lasting bureaucratic repercussions. For 
example, both organisations sometimes use interchangeably documents like maps and repertoires. I realised it when the STE team I was following struggled to find a customer house as the address did not match. After asking our ways to neighbours, the team leader finally told me he had been using the SNE addressing system. Apparently, the agent team leader held documents dating back to the STEE years. Several accounts confirmed that such mismatches were common and delayed works and schedules. Besides, the STE has been nearing bankruptcy for years. The company maintains its activities only owing to uninterrupted state-granted loans (Cabinet Merlin, 2018a, p. 102).

Illustration 5 - STE workers setting on fire to soften devices and PVC pipes during a maintenance operation

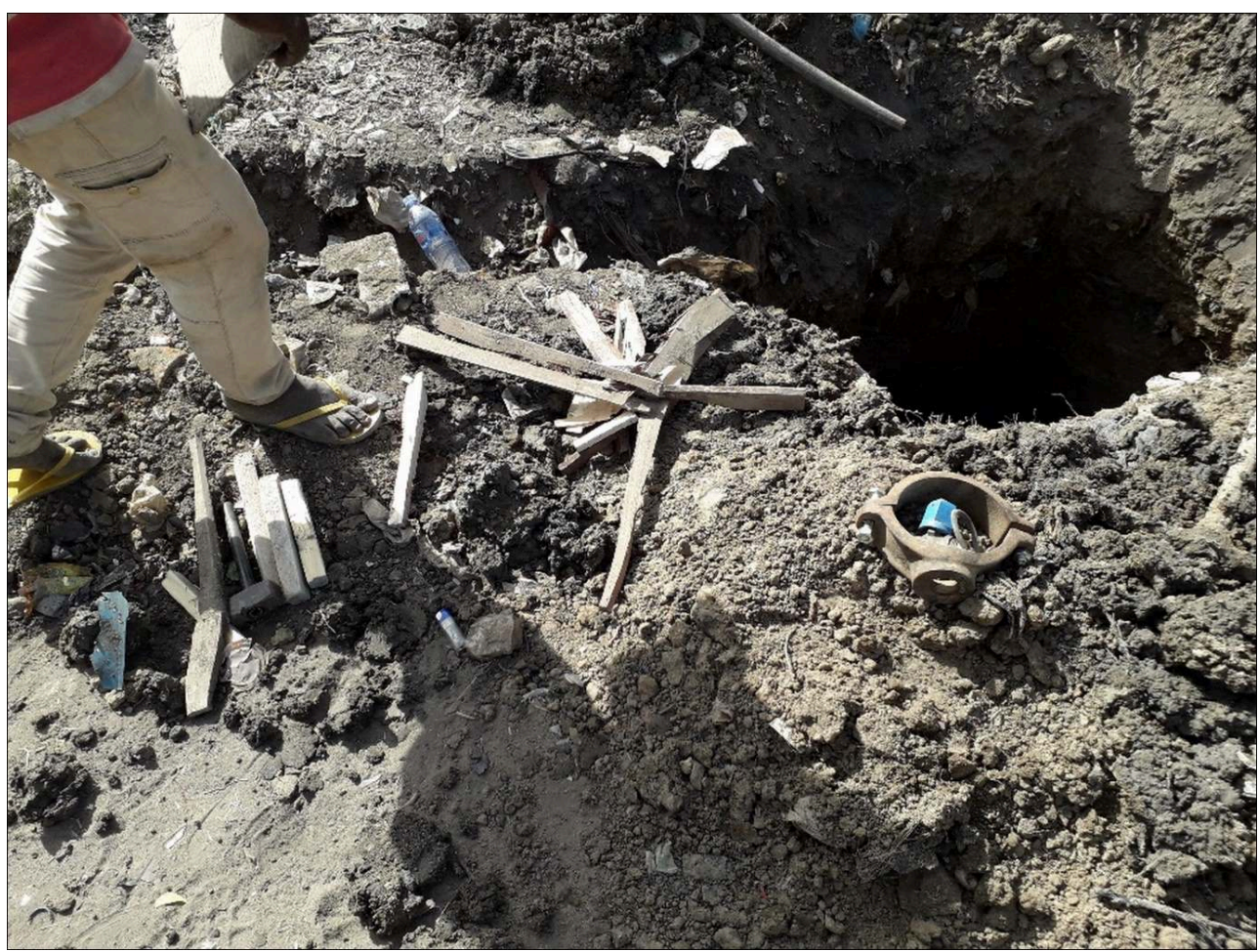

Author: I. Maazaz, 2019

A gap exists between the relative affluence of targeted neighbourhoods located in the inner city and the limited resources available to STE agents. All operations I observed were taking place in district 1 or 2, as exemplified by our visit in Mardjan Daffack to increase water pressure for a subscriber. For urbanites in developing countries, access to water matters strikingly in the sense of belonging the city. Nikhil Anand argues that numerous material and social processes engineer diverging "hydraulic citizenships" (2017, p. 8). As said before, connecting to the STE supply network requires financial means. As such, maintenance and connection operations remain circumscribed to central neighbourhoods. A number of factors play out. The limited extension of pipe networks to neighbourhoods of the old core across the city is an obvious weakness. In addition, costs associated with subscription to the STE supply network create a threshold quickly hit by the pool of potential subscribers. 


\section{Transforming the network: STE and developmental projects}

Beyond the small-scale operations described above, some medium to-large operations that aim at transforming and extending water catchment and distribution. While workers may sort a private customer connection or carry out maintenance tasks in a day of (difficult) labour, more sophisticated operations logically necessitate months of work. I once observed STE teams connecting a new residential building located in the city centre, belonging to the United States embassy. The PVC pipes were already in places. STE workers confirmed that the operation was nearing its end and the only thing left was cutting the pipe and connecting the tee. Regularly, staff were arriving to bring additional materials. This was a several floor building (very rare in N'Djamena) and operations were obviously more complex than for single house connections. This required tees, which managed more water pressure than simple collar pipes, used to connect to the public water valve. As such, this operation heavily involved and modified the public space of one of the busiest central areas of N'Djamena. I followed two STE agents who reached the valve located at a bustling junction, to reduce the water pressure before cutting the PVC pipes. They poured down water to lubricate the hole, cleaning it from dust which had accumulated. Then the agents forced the valve with strength. The junction hosted many commercial stalls selling phones chips and other telecommunication equipment, attracting many people. The STE work disrupted the traffic. Besides, lowering the pressure at the valve affected the whole street, which contained high-end restaurants and villas: people in buildings around were suddenly unable to flush or run tap water properly. Hence, STE agents felt the pressure and they needed to act quickly to avoid complaints. The operation took place in public spaces at the benefit of a single building but visible and impacting many more. 
Illustration 6 - Large PVC pipes channelled to the construction site in front of Barkhane military headquarter

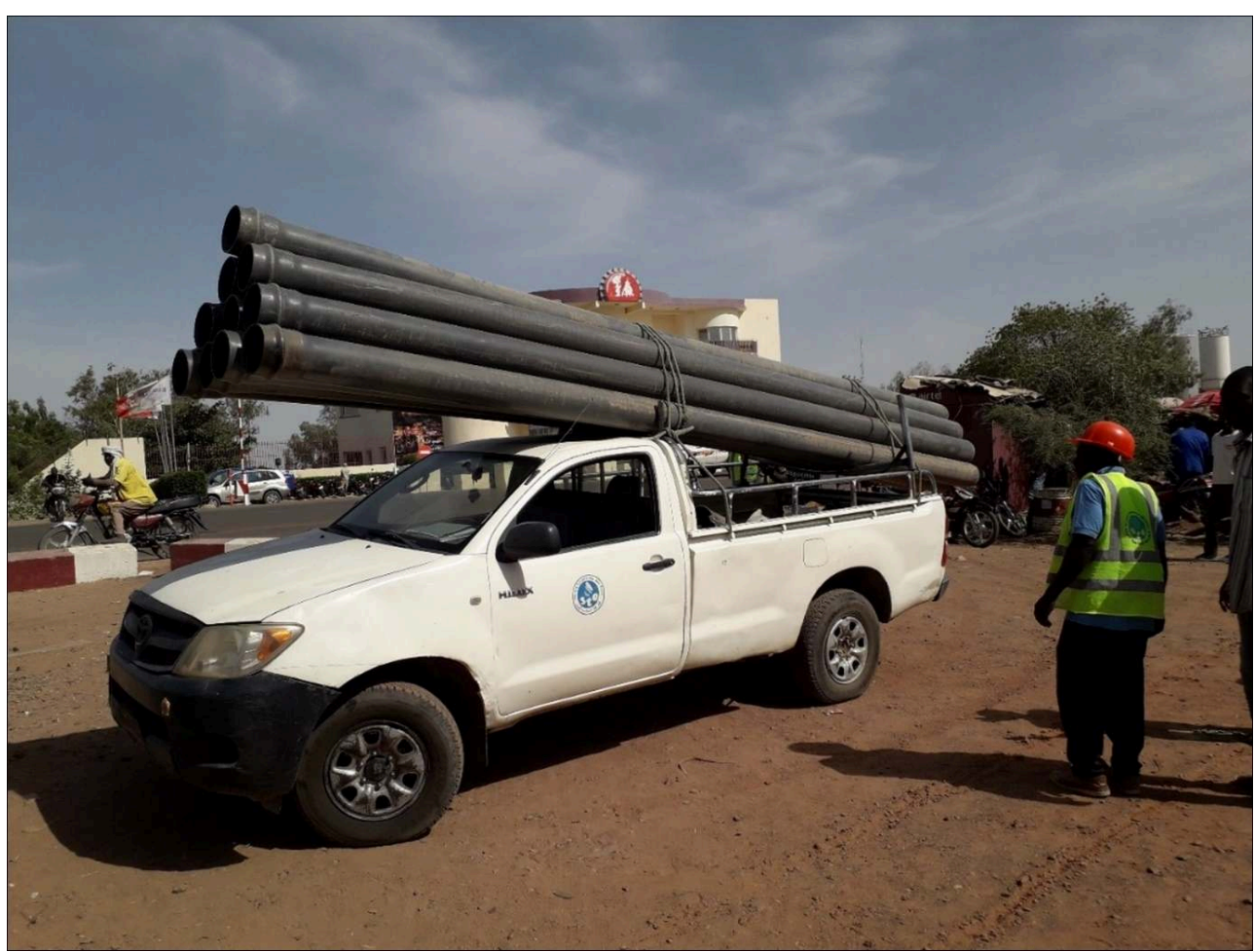

Author: I. Maazaz, 2019.

Meanwhile, STE operations directly transformed the public spaces, sometimes in conjunction with urban development projects. I once followed STE teams working in front of the Barkhane military base ${ }^{8}$. The STE had started working around a month earlier. Agents were burying pipes in a buffer zone between the road and the base to cater the water catchment area of the Develop to Build (D2B) development project. Launched in 2017, the D2B received support from the EU and the Netherlands Enterprise agency, a Dutch public agency tackling sustainable development and innovative and international business. D2B intends to raise water private connections to the STE to $80 \%$ of the N'Djamenois by 2030, strengthen the water supply network in existing parts, increase the management capacity of the STE, as well as mitigate waterborne disease spread (Cabinet Merlin, 2018b, p. 5). This requires establishing a huge catchment area in peripheral N'Djamena. Several water professionals I talked to believe that the D2B project would “end" water problems in N'Djamena. This day, STE agents were positioning pipes while others were digging trenches. Workers were burying warning grids to pinpoint the locations of the pipes, a procedure never followed on smaller operations. Tools and materials were being carried onsite gradually and around 20 STE agents were working.

The work was progressing very effectively but long-term effects of the ongoing work would need further assessment. Indeed, water catchment also necessitates tools for distribution. This nuance goes back to the distinction between water availability and access. Even when households have a piped network on range, they still need to consent to subscription costs to become STE customers. Water end-users with established access to steady and inexpensive water sources like boreholes are unlikely 
to subscribe to the STE, regardless of the subsidies they receive from public authorities and foreign agencies and the existence of a pipe network nearby.

Therefore, other projects attempt to intervene more directly on supply infrastructure. For example, the French development Agency (AFD) is at the forefront of water and sanitation development projects in N'Djamena. Launched in 2013 jointly with the European Union for a total budget of 27 million euros, the Projet de Renforcement de l'Accès à l'Eau et à l'Assainissement de N'Djamena (Water access and Sanitation strengthening in N'Djamena project, PEAN) aims at improving water access and sanitation in the $7^{\text {th }}$ and $8^{\text {th }}$ districts. Those are fast-growing, peripheral districts of Northern and Eastern N'Djamena, which host around $20 \%$ of the city's current population. The project involved building there 1,100 latrines, 21 kilometres of water pipe and 25 water fountains among other objectives. As such, it is expected to simultaneously increase access to publicly managed water sources (fountains) and private connections to the STE.

\section{Coexisting water regimes: the prevailing bricolages}

\section{Competition or coexistence?}

Illustration 7 - Company workers digging a borehole in a private property

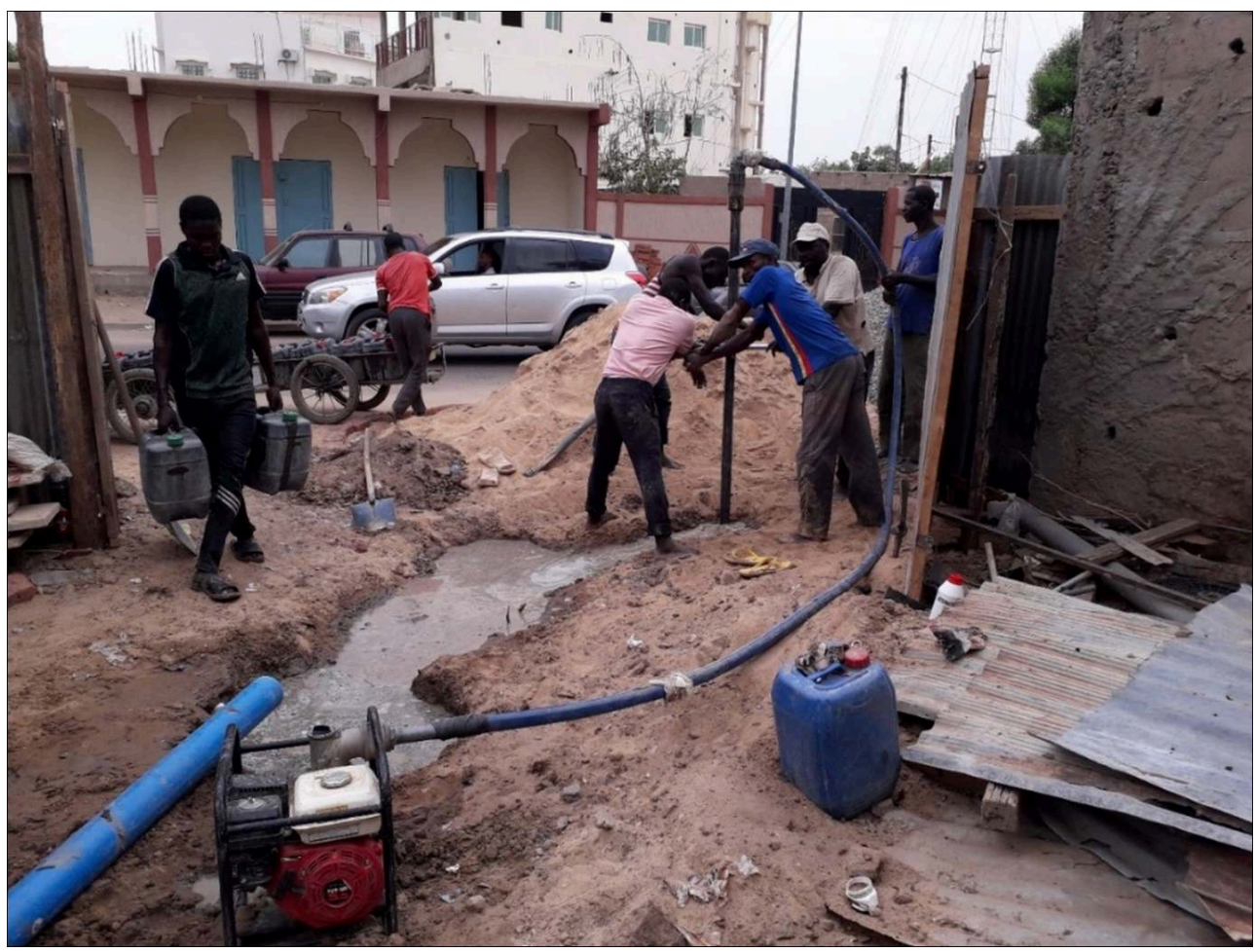

Author: I. Maazaz, 2019

Policy-makers have voiced concerns regarding potential "clashes" or "competitions" between water regimes in N'Djamena against the backdrops of quick urban growth. Seemingly fragmented or splintered hydraulic landscapes can lead experts to question the relevance of infrastructural transformations like the ones presented above in a context where "hybrid delivery configurations" prevail. Yet, such transformations 
might not dismantle the existing multiplicity. Despite the expansion of the STE pipe networks, catchment capacity and coverage, several water regimes persist in N'Djamena. For instance, one may find "lapse" STE customers, punctually relying on other ways to access water despite financial constraints. In the working-class neighbourhood of Paris-Congo ( $6^{\text {th }}$ district) for example, a customer I interviewed detailed how his household suddenly stopped paying STE water bills because they could not afford it anymore. The household subsequently returned to obtaining water from hand pumps, by far the most popular water source in N'Djamena. This is a recurrent story heard across working-class and peripheral neighbourhoods where financial hardships are frequent. Developers or charities sometimes construe cheap hand pumps as a disposable, costless donation. Construction costs for a hand pump may start as low as 300,000 FCFA (around 440 euros). Such budget water sources provide poor water standards as a result from quick oxidisation, giving water a metallic flavour. Poor quality materials and structure added to inadequate utilisation by end-users lead to regular breakdowns, as early as 6 months after setting up the hand pump. Additionally, funding and trained technicians available for maintenance are limited. As such, peripheral neighbourhoods of N'Djamena are sometimes dotted with broken, abandoned hand pumps left to rust. These broken devices have become ruins, "marginalised structures that continue to inform social modes of organisations but that cease to function in ways they once did" (Stoler, 2013, p. 22).

Only relatively wealthy households may carry costs associated with private borehole construction but their numbers are increasing. Many wealthier end-users turn to private boreholes instead of seeking STE subscriptions and borehole owners are very unlikely to ever connect to the piped network, regardless of the incentives devised by the STE or public authorities. Such incentives include "subscription discounts" designed by the STE in consultation with its partners (the City Hall and the French Development Agency) to attract more customers, deducing up to $50 \%$ of associated costs. Yet, poorer would-be customers would still struggle to afford subscription and remain reluctant to connect to the network.

Motivations to build a borehole are premised on various factors, the most obvious one being the absence of STE coverage. A distrust of the STE, sometimes construed as an unreliable company unable to meet supply standards, may also factor in the decision of end-users. Boreholes provide reliable water and carries limited maintenance costs as opposed to regular STE payments, even if STE water tariffs remain low 9 . Yet, a general aversion to networks can also motivate borehole digging as they may enable end-users to emancipate from them. Water access autonomy is sometimes construed as more valuable and desirable than dependence over unreliable large-scale technical networks. For instance, some owners of comfortable villas in Béguinage, a central neighbourhood in the old core, choose to use boreholes despite being at reach of STE supply network. As noted by a professional of the borehole business, regulations on borehole digging in N'Djamena amount to virtually nothing: anybody with sufficient financial resources can dig a borehole in their garden and even sell its water or give it for free. Besides, owning a private borehole displays higher economic and social standards linked to selfsufficiency. As such, observations point at the fact that an extended network would not bring to an end the multiplicity of water supply regimes in N'Djamena. This echoes the case of various metropolises in the region: in Douala, end-users and private providers rely on multiple technical systems, sometimes deploying an ingénierie artisanale 
(artisanal engineering) to model various water supply schemes (Nantchop Tenkap, 2017, p. 193).

29 Various boreholes often service more than one household and become small-scaled "micro" networks (Crombé and Blanchon, 2010; Lavie and Marshall, 2019). Likewise, borehole ownership enables end-users to increase their influence through providing assistance for neighbours in need. In western societies, good domestic waters have gradually developed as opposed to bad public waters as domesticity has learnt to "tame" free waters and reject to the public sphere threatening, unhealthy ones (Kaika, 2015). In Chad though, building boreholes servicing faucets in outdoor locations of houses, like open courtyards, insure both comfort and respect. Patronage dynamics often emerge as a result from the construction of a large private source of water, which fuel symbolical power for the "sons of the soil" (Gomez-Temesio, 2016), who are called upon to help when water solutions cannot be found otherwise, for example to fix a borehole. Furthermore, the water household economy is an example of urban treatment of "people as infrastructures" (Simone, 2004). The absence of universal networks bestows upon household members the role to carry buckets in different rooms.

\section{Various users, various regimes}

Considering "sociotechnical coexistence" (Furlong, 2014) is useful to analyse water supply in developing countries. Water access regimes are not necessarily mutually exclusive: lower-income households may diversify their water sources, improvise and carve out their own multi-sourced water mix to balance quality and costs. This represents another facet of the hydraulic bricolages. For example, I spoke to end-users in Habena ( $7^{\text {th }}$ district) who would fetch free water to a nearby handpump for housewashing and buy drinking water from a water porter operating from a fountain. Water quality and its perception critically factors in the opportunity choices envisioned by end-users (Lavie et al., 2020). Others would benefit from their neighbours' generosity and rely on their private borehole to drink whilst using a free street handpump for other usages. Existing relations with the STE are multifarious and complex. For example, several households may join to use collectively water counters and spread costs. Connection, disconnection, "bad" or "mediocre" connection to the STE network: rather than binary distinctions, water delivery displays a complex "situational continuum" (Jaglin, 2004) that shapes end-users lives.

31 Arguably, the coexistence of several water regimes does not imply that patterns are not currently changing. People with sufficient resources build increasing numbers of boreholes in N'Djamena and transform the waterscape of the city. Exogenous factors related to urban growth influence this trend. For example, I interviewed a neighbourhood association coordinator who interprets the increasing amounts of boreholes in peripheral neighbourhoods as resulting from land valorisation: rising land prices drive away working classes and attract increasingly privileged households ${ }^{10}$. This teleological argument posits that growing land value crowds out public water end-users through a process of "water gentrification": wealthy residents find relying on public fountains contrived and want their own home water scheme, even if they live in an area deprived from piped network. End-users with increasing purchasing power will likely become averse to collection in street fountains or reliance over water porting. 
Here, fluctuations in the estate market determine in part water access strategies and decisions.

Interestingly, global water corporations have shown little interest for Chad so far. For example, Veolia cooperates in different ways with national water companies of Niger and Burkina Faso (Baron, 2014) but no plan to enter Chad has been devised yet. The limited pool of subscribers and profit prospects seem to put foreign private actors off from settling permanently in this sector. As such, the debate around privatising water supply in Chad has not reached the same stage as in neighbouring countries. Conversely, developmental projects on water and sanitation hold much significance in framing the waterscape. The AFD-led PEAN project offers several paths towards water access and may reinforce existing hydraulic bricolages. Its blueprints tackle simultaneously domestic water delivery and public water access, suggesting these are not contradictory goals. Pipes set up as part of the project service both customers' pools: public fountains and private connections ; pipes simultaneously stomers. Project partners such as the municipal officers I interviewed understand this dyadic perspective. They assert to community leaders the potential improvements for their constituents' lives, both through "getting wired" and to having a nearby fountain available, but they know that many residents cannot afford private tap waters and will keep relying on public fountains. Albeit contradictory in appearance, such objectives concern different categories of end-users and actors recognise that such categorisations will prevail. This involves diverging but established socialities, relations to the public space and to the state.

\section{Conclusion}

This paper has investigated the hydraulic bricolages in access and supply that prevail in N'Djamena. Coexisting water regimes, heterogeneous or hybrid delivery configurations characterise N'Djamena waterscape in a city that has never held universal, integrated water supply networks. The daily struggle of STE workers to maintain and extend the network backed by empirical observations accounts for the bricolages. While bigger infrastructural endeavours extending access to the STE are underway, the growing numbers of boreholes offsets the impact of infrastructural expansions and fuel the existing bricolages. End-users and providers riutinely use mixed-water sourcing strategies and tactics.

In April 2020, late President Idriss Deby announced that the Chadian state would cover all STE water bills for a duration of 6 months to help people cope with the Covid-19 pandemic. The provision ended in October 2020 and formed part of an economic emergency package, which included a "vulnerable population solidarity fund", help with electricity bills and tax cuts. Yet, this unprecedented move carried unexpected side effects such as increased power rolling blackouts and reduced water supply pressure as the network struggled to catch up with demand requirements. Covid-19 and associated policies to cope with the pandemic reportedly exacerbated existing tensions on water access in Chad. Curfew and lockdown measures increased the already dramatic hardships and difficulties of water end-users, as measures officially banned poor people from fetching water to local hand pumps or water towers and businesses shutting down left households without incomes. Instead of all-encompassing policies and economic packages which often have unintended adverse consequences on existing 
arrangements, daily practitioners of hydraulic bricolages are perhaps expecting some recognition of their agency and ability to access and distribute water under challenging conditions. This recognition would provide the basis for better-suited actions undergirding the multiplicity of water supply schemes.

\section{BIBLIOGRAPHY}

Ahlers R., Cleaver,F., Rusca, M., and Schwartz, K., 2014. Informal Space in the Urban Waterscape: Disaggregation and Co-Production of Water Services. Water Alternatives, vol. 7, n²1, p. 1-14.

Akrich M., 1989. La construction d'un système socio-technique. Esquisse pour une anthropologie des techniques. Anthropologie et Sociétés, vol. 13, n², p. 31-54.

Anand N., 2011. PRESSURE: The PoliTechnics of Water Supply in Mumbai. Cultural Anthropology, vol. $26, \mathrm{n}^{\circ} 4$, p. 542-564.

Anand N., 2017. Hydraulic City: Water and the Infrastructures of Citizenship in Mumbai. Durham, Duke University Press.

Bakker K., 2003. Archipelagos and Networks: Urbanization and Water Privatization in the South. The Geographical Journal, vol. 169, n 4, p. 328-341.

Baron C., 2014. Approvisionnement en eau et assainissement dans les quartiers défavorisés de villes africaines : état des lieux illustré à travers les cas de Ouagadougou et Niamey. In Naulet F., Gilquin C., Leyronas S., Eau potable et assainissement dans les villes du Sud : la difficile intégration des quartiers défavorisés aux politiques urbaines. Paris, AFD éditions, p. 24-33.

Cabinet Merlin, 2018a. Études pour la réhabilitation et l'extension de l'alimentation en eau potable de N'djamena. Étude diagnostique de la société des eaux tchadienne. Document provisoire. N'Djamena: Netherlands Entreprise Agency, Ministère de l'Eau et de l'Assainissement de la République du Tchad.

Cabinet Merlin, 2018b. Études pour la réhabilitation et l'extension de l'alimentation en eau potable de n'djaména. Étude institutionnelle." Document provisoire. N’Djamena: Netherlands Entreprise Agency, Ministère de l'Eau et de l'Assainissement de la République du Tchad.

Certeau M. de, 1984. The Practice of Everyday Life. Berkeley, University of California Press.

Chauvin E., Langlois O., Seignobos C., Baroin C.,2020. Introduction. Les Conflits, Les Violences et Les Risques Dans Le Bassin Du Lac Tchad. In Chauvin E., Langlois O., Seignobos C., Baroin C., Conflits et Violences Dans Le Bassin Du Lac Tchad. Actes Du XVII Colloque Méga-Tchad. Marseille, IRD Editions, p. 15-34.

Coutard O., 2008. Placing Splintering Urbanism: Introduction. Geoforum, vol. 39, nº 6, p. 1815-1820.

Coutard O.,Rutherford J., 2016. Beyond the Networked City: An Introduction. In Coutard O., Rutherford J., Beyond the Networked City: Infrastructure Reconfigurations and Urban Change in the North and South. London, Routledge, p. 1-25.

Crombé L., 2017. Enjeux d'échelles, enjeux politiques : l'approvisionnement et l'accès à l'eau dans les quartiers périphériques du Grand Khartoum (Soudan). PhD Thesis in Geography, Paris 10 University. 
Crombé L., Blanchon D., 2010. Les (micro)-réseaux à la reconquête de la ville : le cas de Khartoum. Bulletin de l'Association de Géographes Français, vol. 87 n 4, p. 517-533.

Debos M., 2016. Living by the Gun in Chad: Combatants, Impunity and State Formation. London, Zed Books.

Dill B., Crow B., 2014., The Colonial Roots of Inequality: Access to Water in Urban East Africa. Water International, vol. 39, $\mathrm{n}^{\circ}$ 2, p. 187-200.

Furlong K., 2014. STS beyond the 'Modern Infrastructure Ideal': Extending Theory by Engaging with Infrastructure Challenges in the South. Technology in Society, vol. 38, p. 139-147.

Furlong K., 2016. Rethinking Universality and Disrepair: Seeking Infrastructure Coexistence in Quibido, Colombia. In Coutard O., Rutherford J., Beyond the Networked City. Infrastructure Reconfigurations and Urban Change in the North and South. London, Routledge, p. 94-114.

Gomez-Temesio V. 2016. Home Is Claiming for Rights: The Moral Economy of Water Provision in Rural Senegal. Society \& Natural Resources, p. 1-14.

Graham S., Marvin S., 2001. Splintering Urbanism: Networked Infrastructures, Technological Mobilities and the Urban Condition. London, Routledge.

Graham S., Thrift N., 2007. Out of Order: Understanding Repair and Maintenance. Theory, Culture \& Society, vol. $24, \mathrm{n}^{\circ} 3$, p. 1-25.

GWOPA, UN Habitat, DFID. 2015. Société Tchadienne Des Eaux. Performance Improvement Plan. Bonn: Global Water Operators Partnerships Alliance. URL: https://docplayer.fr/51673009-Societetchadienne-des-eaux.html

Hughes T., 1987. The Evolution of Large Technological Systems. In Bijker W., Hughes T., Pinch T., The Social Construction of Technological Systems: New Directions in the Sociology and History of Technology, p. 45-76. Cambridge, MIT Press.

Jackson S., 2014. Rethinking Repair. In Gillepsie T., Boczkowski P., Foot,K., Media Technologies. Essays on Communication, Materiality and Society. Cambridge, The MIT Press, p. 221-240.

Jaglin S., 2004. Être branché ou pas : les entre-deux des villes du Sud. Flux, vol. 2, n 56-57, p. 4-12. Jaglin S., 2005. Services d'eau en Afrique subsaharienne : la fragmentation urbaine en question. Paris, CNRS éditions.

Jaglin S., 2016. Is the Network Challenged by the Pragmatic Turn in African Cities? Urban Transition and Hybrid Delivery Configurations. In Coutard O., Rutherford J., Beyond the Networked City. Infrastructure Reconfigurations and Urban Change in the North and South, p. 182-203.

Kaika M., 2015. The Uncanny Materialities of the Everyday. Domesticated Nature as the Invisible 'Other.' In Graham S., McFarlane C., Infrastructural Lives. London, Routledge, p. 139-152.

Keough S., Youngstedt S., 2019. Water, Life, and Profit: Fluid Economies and Cultures of Niamey, Niger. New York, Berghahn Books.

Kooy M., Bakker K., 2008. Splintered Networks: The Colonial and Contemporary Waters of Jakarta. Geoforum vol. 39, nº 6, p. 1843-1858.

Laboratoire National des Eaux. 2018. Rapport de la campagne d'échantillonnage des 50 points d'eaux dans les quartiers périphériques de la ville de N’Djaména. N’Djaména, Mairie de N’Djaména.

Lavie E., Crombé L., Marshall A., 2020. Reconceptualising the Drinking Waterscape through a Grounded Perspective. The Geographical Journal, vol. 186, n² 2, p. 224-236. 
Lavie E., Marshall A., 2019. Avant-postes et résistances à l'universalisation d'un modèle urbain de service public en zone rurale : le cas de l'accès à l'eau potable en périphérie de Mendoza (Argentine). Annales de Géographie, vol. 1, n 725, p. 5-30.

Lawhon M.,Nilsson D., Silver J., Ernstson H., Lwasa S., 2018. Thinking through Heterogeneous Infrastructure Configurations. Urban Studies, vol. 55, $n^{\circ}$ 4, p. 720-732.

Madjigoto R., 2019. N'Djaména : problématique de l'accès à l'eau des quartiers périphériques. Annales de l'Université de Moundou, Série A-Faculté Des Lettres, Arts et Sciences Humaine, vol. 5 nº 2.

Magrin G., 2001. Le sud du Tchad en mutation : des champs de coton aux sirènes de l'or noir. Saint-Maur, Sépia, Cirad.

Magrin G., 2016. The Disappearance of Lake Chad: History of a Myth. Journal of Political Ecology, $n^{\circ} 23$.

Magrin G., Perrier-Bruslé L., 2011. Nouvelles géographies des activités extractives. Introduction. EchoGéo, $\mathrm{n}^{\circ} 17$.

Magrin G., Van Vliet G. 2012. Une Compagnie Pétrolière Chinoise Face á l'enjeu Environnemental Au Tchad. Paris, AFD Éditions.

Mains D., 2019. Under Construction: Technologies of Development in Urban Ethiopia. Durham, Duke University Press.

MATUH, Mairie de N'Djamena. 2008. Document cadre de planification urbaine pour la ville de N'Djaména. Framework document. N'Djaména: Ministère de l'Aménagement du Territoire, de l'Ubanisme et de l'Habitat, Urbaplan.

Nantchop Tenkap V., 2017. Politiques publiques de l'eau et gouvernance urbaine. acteurs et enjeux de l'accès à l'eau potable des populations à Douala (Cameroun). PhD thesis in Geography, Paris Panthéon-Sorbonne.

N'Diekhor Y., 1996. L'eau et la vie urbaine à N'Djamena. PhD thesis in Geography, Abidjan, Université Nationale de Côte d'Ivoire.

N'Dilbé T., 2015. Gouvernance urbaine et aménagement au Tchad : production et attribution des terrains à bâtir à N'Djaména. PhD thesis in Geography, Ngaoundoure, University of Ngaoundoure.

Ngaressem G., 1998. Géographie, croissance urbaine et problème de l'habitat à N'Djaména. PhD thesis in Geography, Abidjan, Université Nationale de Côte d'Ivoire.

Raimond C., Sylvestre F., Dangbet Z., Abderahmane M., 2019. Le Tchad des Lacs. Paris, IRD Éditions. Rip A., Kemp R., 2004. Technological Change. In Malone E., Rayner S., Human Choice and Climate Change. Columbus, Batelle Press, p. 327-399.

Silver J., 2014. Incremental Infrastructures: Material Improvisation and Social Collaboration across Post-Colonial Accra. Urban Geography, vol. 35, n 6, p. 788-804.

Simone A., 2004. People as Infrastructure: Intersecting Fragments in Johannesburg. Public Culture, vol. $16, n^{\circ} 3$, p. 407-429.

Simone A., 2018. Improvised Lives: Rhythms of Endurance in an Urban South. Cambridge, Polity.

Simone A., 2021. Ritornello: 'People as Infrastructure.' Urban Geography. DOI: https://doi.org/ 10.1080/02723638.2021.1894397

Smith A., Stirling A., Berkhout F., 2005. The Governance of Sustainable Socio-Technical Transitions. Research Policy, vol. 34, n 10, p. 1491-1510. 
Stoler A., 2013. Introduction. 'The Rot Remains'. From Ruins to Ruinations. In Stoler A., Imperial Debris. On Ruins and Ruinations. Durham, Duke University Press, p. 1-35.

Tarr J., 1979. Introduction. Journal of Urban History, vol. 5, n 3, p. 275-277.

UNICEF, Ministère de l'Environement, de l'Eau, Hygiéne et Assainissement. 2017. Résultats 2017. Le programme de coopération Tchad-UNICEF 2017-2021 dans le secteur de l'eau, hygiène et assainissement. N’Djaména, Ministère de l'Environement, de l'Eau, Hygiéne et Assainissement.

Université Populaire. 2017. Rapport d'étude socio-economique du volet alimentation en eau potable. N’Djamena, AFD, Commune de la Ville de N'Djamena, Union Européenne.

Vivien A. 2006. N'Djamena naguère Fort-Lamy. Histoire d'une capitale africaine. Saint-Maur-desFossés, SEPIA.

World Bank. 2019. Tchad. Note Sur Le Secteur de l'eau et de l'assainissement. Washington, World Bank Group. URL: https://documents1.worldbank.org/curated/en/990891563355313917/pdf/ Chad-Water-and-Sanitation-Sector-Note.pdf

Zérah M-H. 2008. Splintering Urbanism in Mumbai: Contrasting Trends in a Multilayered Society. Geoforum, vol. 39, n 6, p. 1922-1932.

\section{NOTES}

1. I'm very grateful to the EchoGéo journal issue editors Emilie Lavie and Mathilde Resch, the editorial secretary Karine Delaunay and two anonymous reviewers for their feedback and support.

2. The JMP defines basic drinking water service as originating from an improved water source (protected from contamination) within a 30 minute round trip range.

3. The Travaux Neufs teams are in charge of construction works such as new tap water connections, setting up pipes and others. In practice though, Maintenance and Travaux Neufs teams operate together on all issues notably because of lack of staff.

4. Additionally, policy documents sometimes use interchangeably the notions of "water access" and "water availability", glossing over issues related to cost and time to access already available water (Keough and Youngstedt, 2019, p. 12).

5. District 9 in the Southern bank of the Chari river which comprises the thriving Walia neighbourhood is a particular case, which does not really fit into this breaking into 3 components.

6. Public fountains are usually leased to entrepreneurs through public contracts associating the STE and the City Hall. The leasers (fermiers) often oversea several fountains and are free to hire fountain managers or deputies. However, the details around the lease system cannot be unpacked here.

7. This is also common in Eastern Africa cities like Nairobi or Dar Es Salam where availability of piped water supply is not entirely correlated with wealth and various central and rich neighbourhoods are out of reach from water infrastructural networks (Dill and Crow, 2014).

8. Barkhane is a large military operation of the French army targeting five francophone, older allies of African countries (Mali, Niger, Chad, Burkina Faso, Mauritania). Since 2013, it is headquartered in N'Djamena. As a result, Chad is a strategic country in the French military apparatus in Africa. In 2021, French President Emmanuel Macron announced the end of the operation.

9. Costs for an inexpensive borehole in N'Djamena start around 400000 FCFA (610 euros), although maintenance costs of such poor quality boreholes are substantial and they often 
provide polluted water. Deeper, high-end boreholes may cost up to 5 million FCFA (7 615 euros). Costs are much higher in rural areas.

10. Such processes are also fuelled by uncertain land regulations that drive phenomena like " land colonisation" or squatting (N'Dilbé, 2015).

\section{ABSTRACTS}

This article investigates the ambivalent interconnectedness of water supply regimes of N'Djamena, the Chadian capital. Multiple water supply regimes coexist in N'Djamena and produce what I termed "hydraulic bricolages". The article documents daily activities of the Technical Directorate of the Société Tchadienne des Eaux (Chad's water national company, STE), insisting on limited available means and improvising methods that characterise hydraulic bricolages. The article then turns to alternative regimes, notably based on (cheap) water hand pumps and (costly) private boreholes. It qualifies the notion of "competing" sociotechnical regimes and stresses patterns of coexistence.

Cet article explore les ambivalences de l'interconnexion des régimes d'adduction d'eau potable de N'Djamena, la capitale du Tchad. De multiples régimes coexistent à N'Djamena, produisant ce qu'on appellera des «bricolages hydrauliques ». L'article documente en premier lieu les activités quotidiennes de la Direction Technique de la Société Tchadienne des Eaux (STE), insistant sur les moyens limités des équipes et les méthodes d'improvisation qui caractérisent les bricolages hydrauliques. L'article se penche également sur les régimes alternatifs, fondés notamment sur les pompes à motricité humaine (peu chères) et les forages privés (coûteux). Il nuance l'idée d'une « compétition » de ces régimes sociotechniques et privilégie l'hypothèse d'une coexistence.

\section{INDEX}

Keywords: water regime, bricolage, Chad, infrastructure, urban studies Subjects: Sur le Champ

Mots-clés: régime d'eau, bricolage, Tchad, infrastructure, étude urbaine

\section{AUTHOR}

\section{ISMAËL MAAZAZ}

Ismaël Maazaz, I.E.Maazaz@sms.ed.ac.uk, is a PhD candidate in African Studies, Centre of African Studies, University of Edinburgh (UK). He has recently published:

- Maazaz I., 2018. A Southern Connection: Chadian extraversion policies and the repercussions for the Libyan territory. Egypte/Monde-Arabe [En ligne], n 18. URL: http:// journals.openedition.org/ema/3951 - DOI: https://doi.org/10.4000/ema.3951 